\title{
Viral Üst Solunum Yolu İnfeksiyonu Geçiren Çocuklarda C-Reaktif Protein Düzeyinin ve Nötrofil/Lenfosit Oranının Araştırılması
}

\author{
The Investigation of C-Reactive Protein Levels and Neutrophil/Lymphocyte Ratio in Children \\ With Viral Upper Respiratory Tract Infection
}

Tolga TURAN ${ }^{1}$, Alper AKAY ${ }^{2}$, Ahmet KAPAR ${ }^{3}$, Sema YILMAZ ${ }^{4}$

\author{
${ }^{1}$ Gaziosmanpaşa Eğitim ve Araştırma Hastanesi, Çocuk Sağlığı ve Hastalıkları, İstanbul,Türkiye \\ ${ }^{2}$ Kütahya Sağlık Bilimleri Üniversitesi Tıp Fakültesi, Çocuk Sağlığı ve Hastalıkları Anabilim Dalı, Kütahya,Türkiye \\ ${ }^{3}$ Uşak Üniversitesi Tıp Fakültesi Kadın Doğum ve Çocuk Hastanesi, Çocuk Sağlığı ve Hastalıkları, Uşak, Türkiye \\ ${ }^{4}$ Sağlık Bilimleri Üniversitesi Kartal Dr. Lütfi Kırdar Eğitim ve Araştırma Hastanesi, Çocuk Hematoloji ve Onkoloji, İstanbul,Türkiye
}

\section{Özet}

Amaç: Bu çalışmada çocukluk çağı hastalıkları içinde sık görülen viral üst solunum yolu infeksiyonlarında C-reaktif protein düzeyive nötrofil/lenfosit oranının tanıdaanlamlı olup olamayacağını araştırmayı hedefledik.

Gereç ve Yöntemler: Çalışma viral üst solunum yolu infeksiyonu tanısı almış 1-18 yaş aralığındaki çocuk hastaların kayıtlarıretrospektif olarak incelenerek yapıldı. Tam kan sayımı sonuçlarından nötrofil ve lenfosit değerleri tespit edildi. CRP referans değeri $5 \mathrm{mg} / \mathrm{dL}$; Nötrofil/lenfosit oranı referans aralıkları 0-1, 1-2, 2-3, 3-4, 4-5 ve >5 olarak alındı.C-reaktif protein ve nötrofil/lenfosit oranı düzeyleri korelasyon analizi yöntemi ile karşılaştırıldı.

Bulgular: Yaşları bir ay ile 18 yaş arasında değişmekte olan 100 hasta, 52 kız (\%52) 48 erkek (\%48) kayıt edildi. Kız çocuklarının ortalama yaşı 6,42 $\pm 0,69$,

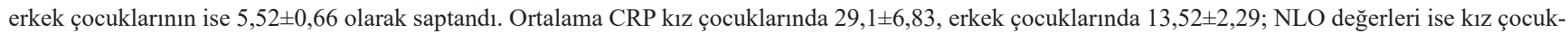

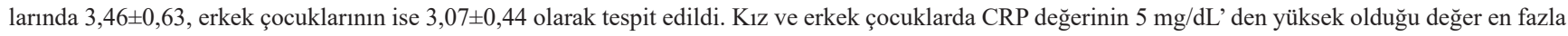
5-9 yaş aralığında görüldü.CRP değerlerine göreerkek ve kızlar arasında anlamlı bir ilişkivardı. NLO değerleri ise 1-2, 2-4 ve 10-18 yaş kız ve erkekler arasında anlamlı bir farka sahipti $(\mathrm{p}<0,001)$. CRP ve NLO değerleri korelasyon analizi ile değerlendirildiğinde, zayıf düzeyde anlamlı ilişkili oldukları saptand $1(\mathrm{r}=0,263)$.

Sonuç: Pediatrik yaş grubunda akut üst solunum yolu infeksiyonlarında C-reaktif protein düzeyi ve nötrofill/lenfosit oranı anlamlı derecede artmıştı. Mevcut çalışmada,erken tanı ve tedaviye yardımcı olması adına pratik, ucuz ve kolay bir metod olan C-reaktif protein düzeyi ile nötrofil/lenfosit oranı vurgulandı. Anahtar Kelimeler: ÜSYE, C-reaktif protein, CRP, Nötrofil/lenfosit oranı

\section{Abstract}

Objective: In this study, we aimed to investigate whether C-reactive protein (CRP) level and neutrophil/ lymphocyte (NLO) ratio can be meaningful in the diagnosis of viral upper respiratory tract diseases which are common in pediatric diseases.

Material and Methods: The study was done retrospectively with investigating of files belonds to children aged between onemonth and 18 years old diagnosed with viral upper respiratory tract infection. Neutrophil/ lymphocyte ratio was determined from complet blood count results. C-reactive protein and neutrophil/lymphocyte ratio levels were stated as $5 \mathrm{mg} / \mathrm{dL}$ and $0-1,1-2,2-3,3-4,4-5$ and $>5$, respectively. C-reactive protein and neutrophil/lymphocyte ratio levels were compared by correlation analysis method.

Results: One hundred of patients, 52 girls (52\%) and 48 boys (48\%),agedbetween one month and 18 years old were recorded. The mean age of girls and boys were $6,42 \pm 0,69$ and 5,52 $\pm 0,66$, respectively. While the mean C-reactive protein levels were $29,1 \pm 6,83$ and $13,52 \pm 2,29$, the mean neutrophil/lymphocyte

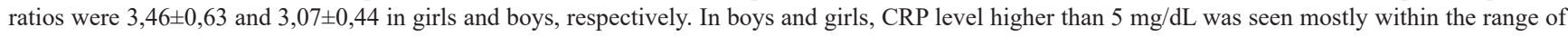
5-9 year old. There was meaningful relationship between girls and boys according to their CRP levels. The difference was statistically significant for NLO levels in children aged 1-2, 2-4 and 10-18 years old $(\mathrm{p}<0,001)$. When C-reactive protein and neutrophil/lymphocyte ratio values were evaluated by correlation analysis, they were found to be weakly significant $(\mathrm{r}=0,263)$.

Conclusion: In the pediatric age group, C-reactive protein levels and neutrophil/lymphocyte ratios were high significantly in acute upper respiratory tract infections. In the present study, C-reactive protein and neutrophil/lymphocyte ratio which are practical, cheap and easy method were emphasized in terms of asistingboth an early diagnosis and treatment.

Key words: Upper respiratory tract diseases, C-reactive protein, CRP, Neutrophil/ lymphocyte ratio, NLO

Yazışma Adresi: Sema YILMAZ, Sağlık Bilimleri Üniversitesi Kartal Dr. Lütfi Kırdar Eğitim ve Araştırma Hastanesi, Çocuk Hematoloji ve Onkoloji, İstanbul,Türkiye

Telefon: 0276221 2121, Mail:semayilmaz@hotmail.com

ORCID No (Sirasıly): 0000-0002-3505-3140, 0000-0001-8140-4813, 0000-0003-4186-1336, 0000-0003-4277-3880

Geliş Tarihi: 06.07.2020

Kabul Tarihi: 07.11 .2020

DOI: $10.17517 /$ ksutfd. 765333 


\section{GİRIŞ}

Çocuklarda görülen hastalıkların $\% 75$ ' ini üst solunum yolu infeksiyonları (ÜSYE) oluşturmaktadır. Türkiye' de 0-14 yaş grubunda ölüm nedenleri arasında dokuzuncu sıradadırlar. Bu infeksiyonlar genellikle iyi klinik seyirli olmakla birlikte takip ve tedavileri zamanında ve etkin yapılmadığ takdirde önemli komplikasyonlara yol açabilmektedirler (1). Üst solunum yolu infeksiyonları akut farenjit (tonsillofarenjit), akut larenjit, akut epiglottit, peritonsiller abse ve akut laringotrakeobronşit (krup) olarak sınıflandırılmaktadır. Viral veya bakteriyel, akut ya da kronik olabilir. Çoğunlukla viral etkenler sorumlu olup, ayrıca bakteriyel etkenler de ÜSYE nedeni olmaktadir (2).

Bir infeksiyon ya da inflamasyon belirteci olmasının yanı sıra, çok geniş biyolojik özelliğe ve işleve sahip olan $\mathrm{C}$ reaktif protein (CRP)önemli bir parametredir (3-5). Nötrofil/lenfosit oranı (NLO), tam kan testindeki nötrofil ve lenfosit değerleri kullanılarak hesaplanan ve günümüzde önemi günden güne artan bir göstergedir. NLO genellikle subklinik inflamasyonun göstergesi olarak kabul edilmektedir. Pek çok çalışmada vurgulandığı gibi nötrofil/lenfosit oranının bazı hastalıklar açısından bir belirteç olabileceği gösterilmiştir $(6,7)$.

Mevcut çalışmamız ile çocuklarda sık görülen üst solunum yolu infeksiyonlarında hem CRP düzeyine hem de nötrofil/lenfosit oranına bakarak bu parametrelerin tanıya ne kadar yön verebileceğini araştırmayı hedefledik. Sonuç olarak, bu çalışmada CRP değerinin ve nötrofil/lenfosit oranının değerlendirilmesiyle elde edilecek verilerin hekimlereışık tutabileceği, ayrıca bu konuda yapılacak diğer çalışmalara da kaynak oluşturabileceği planlandı.

\section{GEREÇ ve YÖNTEMLER}

Kütahya Sağlık Bilimleri Üniversitesi Evliya Çelebi Eğitim ve Araştırma Hastanesi Çocuk Sağlı̆̆ı ve Hastalıkları polikliniğinde viral üst solunum yolu infeksiyonu tanısı almış çocuk hastaların bir yıllık kayıtları retrospektif olarak incelendi. Çalışma için Klinik Araştırmalar Etik Kurulu'ndan etik kurul onayı alındı. Çalışma Helsinki Deklerasyonuna uygun olarak yürütüldü.

Viral üst solunum yolu infeksiyonu tanısı hem klinik değerlendirme hem de burun mukozasından direk alınan sekresyon örneğindehızlı antijen testi ile A grubu beta hemolitik Streptokok infeksiyonu dışlanarak; hızlıinfluenza testi ile doğrulanarak çalışmaya alınan 100 çocuğun tam kan sayımları ile C-reaktif protein (CRP) sonuçları hasta kayıtlarından elde edildi.İlk başvuru anındaki tam kan sayımı sonuçlarından da nötrofil ve lenfosit değerleri tespit edildi. Çalışmaya alınan hastaların tam kan testi sonuçlarından nötrofil sayısı lenfosit sayısına oranlanarak NLO değerleri hesaplandı. Nötrofil/lenfosit oranı referans aralıkları $0-1 ; 1-2 ; 2-3 ; 3-4 ; 4-5$ ve $>5$ olarak alındı (8). Ayrıca tüm hastalara ait yaş ve cinsiyet verileri de kayıt edildi. Antimikrobiyal tedavi kullanmış, immün yetmezlik ve kronik hastalık tanısı olan hastalar, verilerine tam olarak ulaşılamayan, konjenital anomalisi, peri- natal hipoksi öyküsü, metabolik hastalık tanısı almış ve kan transfüzyonu alan hastalar çalışmaya alınmadı. Tam kan sayımı Beckman Coulter LH 780 Gen-S otomatize hematoloji cihazı ile (Beckman Coulter. Miami, FL, USA);serum CRP düzeyleri ise türbidimetrik metoda dayalı Beckman Coulter AU680 cihazı ile (Beckman Coulter, Miami, FL, USA) yapılan ölçümlerden elde edildi.

\section{İstatistiksel Analiz}

Statistical Package for Social Sciences for Windows version 17,0 (SPSS, Chicago, IL, ABD) programı kullanıldı. Tanımlayıcı veriler ortalama \pm standart sapma, sayılar ve yüzdelerle ifade edildi. Hastaların verilerinin dağılımları Kolmogorov - Smirnov testi ile değerlendirildi. CRP ve NLO Değerlerinin anlamlı düzeyde ilişkili olup olmadığı, ilişkili ise bu ilişkinin şiddeti, korelasyon analizi ile test edildi. CRP ve NLO düzeyleri için her bir yaş grubundaiki cinsiyet arasındaki iki grup karşılaştırılmasında Student T testi kullanıldı. İstatistikî farklılıkları değerlendirebilmek için $\mathrm{p}<0,05$ düzeyi istatistikî yönden anlamlı kabul edildi.

\section{BULGULAR}

Yaşları bir ay ile 18 yaş arasındaki 100 hasta, 52'si kız (\%52) ve 48'i (\%48) erkek olarak kayıt edildi. Kız çocuklar1-

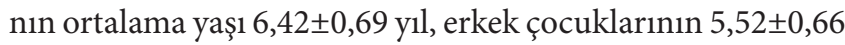
olarak saptandı Ortalama CRP değerleri kız çocuklarında

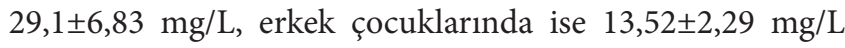
olarak bulundu. Nötrofil/lenfosit oranı ise kız çocukların-

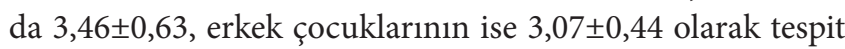
edildi (Tablo 1). CRP değeri $<5$ olan 50 hastada, NLO değerleri 5 ve altında olanlar 44 (\%88), 5 'in üzerinde olanlar 6 (\%12); CRP değeri $>5$ olan hastalarda ise NLO değerleri 5 ve altında olanlar 36 (\%72), 5'in üzerinde olanlar 14 (\%28) olarak tespit edildi (Tablo 2).

\begin{tabular}{|c|c|c|c|}
\hline & Kiz & Erkek & Toplam \\
\hline N (\%) & $52(\% 52)$ & $48(\% 48)$ & $100(\% 100)$ \\
\hline Yaş (yıl) & $6,42 \pm 0,69$ & $5,52 \pm 0,66$ & $5,99 \pm 4,81$ \\
\hline CRP (mg/L) & $29,1 \pm 6,83$ & $13,52 \pm 2,29$ & $21,62 \pm 3,78$ \\
\hline $\begin{array}{l}\text { Nötrofil/lenfosit } \\
\text { oranı (NLO) }\end{array}$ & $3,46 \pm 0,63$ & $3,07 \pm 0,44$ & $3,27 \pm 3,89$ \\
\hline
\end{tabular}

CRP ve NLO değerleri korelasyon analizi ile değerlendirildiğinde, zayıf düzeyde anlamlı ilişkili oldukları saptandı $(\mathrm{r}=0,263)$ (Şekil 1).

Ortalama NLO değerleri ise, 0-1 yaş kızlarda $1,397 \pm 1,4313$, erkeklerde 1,749 $\pm 1,631$ olarak saptand1. Aralarında farklılık istatistiksel olarak anlamlı değildi $(\mathrm{p}=0,128)$. NLO değerleri 1-2 yaş kızlarda ortalama 0,951 $\pm 0,5328$, er-

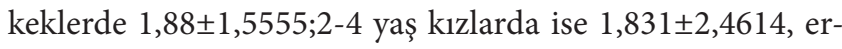
keklerde 4,053 $\pm 1,4111$ olarak saptandı. Aynı yaş grubundaki, 1-2 yaş ile 2-4 yaş, kız ve erkek vakalar arasında yapılan 
karşılaștırmalarda NLO değerleri aralarındaki farklılık istatistiksel olarak anlamlı bulundu $(\mathrm{p}<0,001)$. Ortalama NLO değerleri 5-9 yaş grubu kızlarda 3,883 $\pm 3,3242$, erkeklerde $3,435 \pm 3,5695$ olarak bulundu. Aralarındaki ilişki istatistiksel olarak anlamlı değildi ( $\mathrm{p}=0,454)$.Diğer 10-17 yaş grubunda ise NLO değeri kızlarda ortalama 5,803 $\pm 6,9181$, erkeklerde $3,950 \pm 4,1813$ olarak saptanırken bu yaş grubundaki hastaların arasında belirgin fark görüldü $(\mathrm{p}=<0,001)$ (Tablo 3).

\section{Tablo 2. CRP ve NLO değerlerinin}

\section{karşılaştırılması}

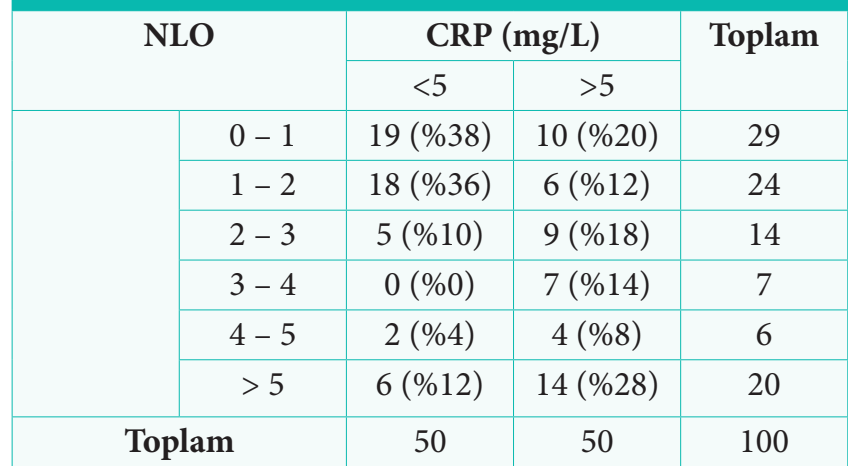

Aynı yaş grubundaki kız ve erkek vakalar arasında yapılan karşılaştırmalarda CRP değerleri aralarındaki farklılık dört yaş grubunda belirgindi ( $\mathrm{p}<0,001)$. Ortalama CRP değerleri ise, 0 - 1 yaş kızlarda 7,0 $\pm 10,258$, erkeklerde $10,0 \pm 12,207$ olarak saptand1.

$\mathrm{Bu}$ yaş grubunda CRP değerleri arasında istatistiksel olarak anlamlı farklılık bulunamazken $(\mathrm{p}=0,128)$; 1 -2 yaş kızlarda 2,75 $\pm 3,095$ ve erkeklerde 9,6 $\pm 7,765$ olarak bulunan

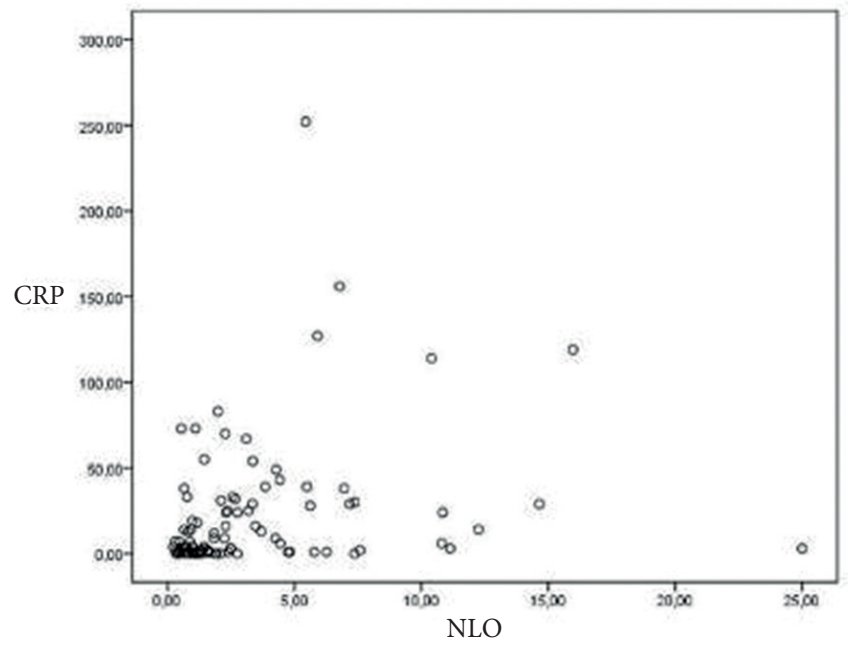

Şekil 1. CRP ve NLO değerleri korelasyon analizi

Tablo 3. Farklı yaş gruplarına ait NLO değerlerinin cinsiyetlere göre karşılaştırması

\begin{tabular}{|c|c|c|c|c|c|}
\hline Yaş (yıl) & Cins & $n$ & Ortalama & Standart Sapma & $p$ \\
\hline \multirow[t]{2}{*}{$0-1$} & $\mathrm{~K}_{12}$ & 10 & 1,397 & 1,4313 & \multirow[t]{2}{*}{0,128} \\
\hline & Erkek & 11 & 1,749 & 1,6310 & \\
\hline \multirow[t]{2}{*}{$1-2$} & $\mathrm{~K}_{1 z}$ & 4 & 0,951 & 0,5328 & \multirow[t]{2}{*}{$<0,001$} \\
\hline & Erkek & 5 & 1,880 & 1,5555 & \\
\hline \multirow[t]{2}{*}{$2-4$} & Kız & 7 & 1,831 & 2,4614 & \multirow[t]{2}{*}{$<0,001$} \\
\hline & Erkek & 6 & 4,053 & 1,4110 & \\
\hline \multirow[t]{2}{*}{$5-9$} & Kız & 16 & 3,883 & 3,3242 & \multirow[t]{2}{*}{0,454} \\
\hline & Erkek & 16 & 3,435 & 3,5695 & \\
\hline \multirow[t]{2}{*}{$10-17$} & Kiz & 15 & 5,803 & 6,9181 & \multirow[t]{2}{*}{$<0,001$} \\
\hline & Erkek & 10 & 3,950 & 4,1813 & \\
\hline
\end{tabular}

Tablo 4. Farklı Yaş Gruplarına Ait CRP Değerlerinin Cinsiyetler Arası Karşılaştırması

\begin{tabular}{|c|c|c|c|c|c|}
\hline Yaş (yıl) & Cins & $n$ & Ortalama & Standart Sapma & $p$ \\
\hline \multirow[t]{2}{*}{$0-1$} & $\mathrm{~K}_{1 Z}$ & 10 & 7,0 & 10,257 & \multirow[t]{2}{*}{0,128} \\
\hline & Erkek & 11 & 10,0 & 12,207 & \\
\hline \multirow[t]{2}{*}{$1-2$} & Kız & 4 & 2,75 & 3,095 & \multirow[t]{2}{*}{$<0,001$} \\
\hline & Erkek & 5 & 9,6 & 7,765 & \\
\hline \multirow[t]{2}{*}{$2-4$} & $\mathrm{~K} 1 \mathrm{Z}$ & 7 & 16,86 & 19,668 & \multirow[t]{2}{*}{$<0,001$} \\
\hline & Erkek & 6 & 27,33 & 15,552 & \\
\hline \multirow[t]{2}{*}{$5-9$} & $\mathrm{~K}_{1 Z}$ & 16 & 59,88 & 71,367 & \multirow[t]{2}{*}{0,454} \\
\hline & Erkek & 16 & 17,38 & 19,714 & \\
\hline \multirow[t]{2}{*}{$10-17$} & Kiz & 15 & 23,73 & 37,579 & \multirow[t]{2}{*}{$<0,001$} \\
\hline & Erkek & 10 & 4,9 & 9,362 & \\
\hline
\end{tabular}


sonuçlar istatistikseldüzeyde farklıdı $(\mathrm{p}<0,001)$. Yine hem 2-4 yaş hem de 5-9 yaş grubu kız ve erkek hastalar arasındaki CRP değerleri belirgin şekildeanlamlıydı $(p<0,001)$. Ayrıca 10-17 yaş grubunda kızlarda ortalama CRP değeri

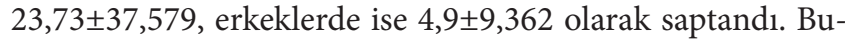
değerler arasındaki ilişki istatistiksel olarak farklılık içeriyor$\mathrm{du}(\mathrm{p}<0,001)$ (Tablo 4).

\section{TARTIŞMA}

Üst solunum yolu infeksiyonları çocuk yaş grubunda oldukça sık görülmektedir ve mortalitenin önemli bir sebebidir. Literatüre bakıldığında, üst solunum yolu infeksiyonu, 5-9 yaş grubunda daha sık görülmekte olup, çalışmamızda da en büyük olgu grubunu 5-9 yaş vakalar oluşturmuştur. Pediatrik yaş grubunda yapılan bir çalışmada akut ÜSYE, erkek olgularda daha sık görülürken (9) çalışmamızda kız ve erkek oranı eșit idi.

Günümüzde klinik pratikte bakteriyel infeksiyon tanısında kullanılabilecek biyobelirteçler oldukça çeşitlidir. En sık kullanılan akut faz reaktanları CRP, lökosit sayısı, trombosit sayısı ve sedimentasyondur $(10,11)$. Özellikle lökosit sayısı bakteriyel infeksiyon tanısında tek başına özgün olmayabilir. CRP düzeyinin de akut infeksiyonlar dışında yanık, travma, otoinflamatuar hastalıklar, kardiyometabolik hastalıklar, hormon replasman tedavisi, obezite, erken dönem böbrek hastalıkları, statin tedavisi, fiziksel aktivite, sigara kullanımı gibi pek çok farklı durumdan etkilendiği bilinmektedir (12-14). Ayrıca bazı durumlarda bu biyobelirteçlerin infeksiyonu belirlemede de özgün olmadığ 1 ve yeni parametrelere ihtiyaç duyulduğu öne sürülmüş olup, prokalsitonin ve IL-6 gibi belirteçlerin kullanımı gündeme gelmiş, ancak pek çok merkezde bunların çalışılamaması ve maliyetlerinin oldukça yüksek olması kullanımlarını sınırlandırmıştır $(15,16)$.

Mevcut çalışma pediatrik yaş grubunda oldukça sık görülen akut üst solunum yolu infeksiyonlarında CRP ve özellikle klinikte daha az tercih edilen nötrofil lenfosit oranınınkullanılması hızlı, basit, kolay ulaşılabilir, erken tanı ve tedavide fayda sağlayacak ve sağ kalımı artıracak bir biyobelirteç olarakvurgulanması amacıyla yapılmıştır.CRP bir infeksiyon ya da inflamasyon belirteci olmakla birlikte, pek çok durumda artış gösterdiği de bilinmektedir (14).Biz de çalışmamızda, akut üst solunum yolu infeksiyonu geçiren olguların \%50' sinde CRP değerinin laboratuarın referans değeri olan 5 $\mathrm{mg} / \mathrm{L}$ ' den yüksek olduğunu saptadık. Serum CRP düzeyinde anlamlı artı̧ gözlenmeyen \%50'lik grubunda, CRP' nin akut infeksiyonlarda üretimindeki artışının ilk 4-7 saatte başlayıp, 36. saatte pik yapmasından dolayı olduğunu düşünmekteyiz. CRP düzeyleri açısından çeşitli bakteriyel infeksiyonlarda kız ve erkek çocuklar karşılaştırıldığında anlamlı düzeyde fark bulunamamıştır (14).Çalışmamızda ise 0-1 yaş grubu dışındaki tüm gruplarda kız ve erkek çocuklar arasında istatistiksel olarak anlamlı fark saptandı. Çocuklarda yaş ve cinsiyete göre CRP değerlerinin farklı olması bağışık sistemin akut faz reaktanlarına farklı cevap vermesiyle açıklanabilir.

Pek çok çalışmada vurgulandığı gibi nötrofil/lenfosit oranının bazı hastalıklar açısından iyi bir parametre olabileceği gösterilmiştir (17-20). NLO değeri açısından, çalışmamızda $1-2,2-4$ ve $10-18$ yaş gruplarında kız ve erkek açısından istatistikî olarak anlamlı farklılık bulunurken, çalışmanın \%53'ünü oluşturan 0-1 ve 5-9 yaş gruplarında ise beklediğimiz üzere NLO değerinin cinsiyetten etkilenmediği görülmüştür. Geçmiş çalışmalara bakıldığında çeşitli infeksiyonlarda araştırılmış olup, NLO seviyeleri belirlenmiştir (21). Her ne kadar değişik infeksiyonlarda farklı NLO değerleri ifade edilse de; çocuklarda yapılan çalışmalar oldukça azdır. Mevcut araştırmada,ÜSYE tanılı çocuklardaki NLO değerininyaşa göre farklı değerlerirapor edildi. Klinik kullanımı daha yaygın olan ve etkinliği daha kanıtlanmış olan CRP düzeyi ile karşılaştırıldığında, zayıf düzeyde anlamlı ilişkili olduğu saptandı. Özellikle viral ÜSYE tanılı çocuklarda yaşa göre NLO değerlerini inceleyen diğer çalışmalara ihtiyaç vardir.

$\mathrm{Bu}$ araştırmada çocukluk çağındaki akut üst solunum yolu infeksiyonlarında CRP ve NLO değerleri artarhipotezi ile elde edilen sonuçlar benzer doğrultuda bulundu. Ancak bu farkın daha geniş vaka serilerinde doğrulanmaya ihtiyacı olduğunu düşünmekteyiz. Çalışmamız daha önce yapılmış olan çalışmalar ile kıyaslandığında, NLO’ nun pediatrik yaş grubunda akut üst solunum yolu infeksiyonlarında klinik kullanımına yönelik, CRP düzeyi ile karşılaştırılması yöntemi ile yapılmış ilk ve özgün bir çalışmadır.

Mevcut çalışmanın birtakım kısıtlamaları mevcuttur. Çalışmamız öncelikle tek merkezli ve retrospektif bir çalışmadır. Kısıtlı bir vaka grubunda yapılmıştır. Diğer yandan, nötrofil lenfosit oranı pek çok hastalıkta ve vaka grubunda incelenmiş bir biyobelirteç olmasına rağmen, henüz net olarak referans değerleri belirlenmiş değildir.

Sonuç olarak, Pediatrik yaş grubunda akut üst solunum yolu infeksiyonlarında CRP ve NLO düzeyinin istatistiksel olarak anlamlı derecede artmış olduğunu saptadık. Dolayısıla erken tanı ve tedaviye yardımcı olacak, pratik, ucuz ve kolay ulaşılabilecek, sağ kalım üzerine olumlu etkileri olacağını düşündüğümüz NLO değerinin diğer bir bilinen parametre olan CRP ile korelasyon gösteren artışı vurgulanmış oldu. Çalışmamızın pediatrik yaş grubu akut ÜSYE vakalarındahem CRP ve NLO düzeylerini karşılaştıran ilk çalışma olması hem deileride daha geniş kapsamlı araştırmalara öncülük edebileceğini düşünmekteyiz.

${ }^{*}$ Bu çalışma, Kütahya Sağlık Bilimleri Üniversitesi Tıp Fakültesi Çocuk Sağlığı ve Hastalıkları Anabilim Dalı'nda Doç. Dr. Sema Yılmaz'ın danışmanlı̆̆ını yaptığ ${ }_{1}$ Dr. Tolga Turan'ın "Viral Üst Solunum Yolu İnfeksiyonu Geçiren Çocuklarda C-Reaktif Protein Düzeyinin ve Nötrofil/Lenfosit Oranının Araştırılması" başlıklı tıpta uzmanlık tezinden üretilmiştir.

\section{Çıkar çatışması ve finansman beyanı}

Bu çalışmada çıkar çatışması yoktur ve finansman desteği alınmamıştır.

\section{Araştırmacıların katkı oranı beyan özeti}

Yazarlar makaleye eşit katkı sağlamış olduklarını beyan ederler. 


\section{KAYNAKLAR}

1. Set $\mathrm{T}, \mathrm{Avşar}$ Ü. Birinci Basamakta Üst Solunum Yolu İnfeksiyonları: Akut Streptokoksik Tonsillofarenjit ve Romatizmal Ateş. Euras J Fam Med 2013;2:51-6.

2. Canela LNP, Magalhães-Barbosa MC, Raymundo CE, Carney S, Siqueira MM, Prata-Barbosa A, et al. Viral detection profile in children with severe acute respiratory infection.Braz J Infect Dis 2018; 22:402-11. doi: 10.1016/j.bjid.2018.09.001.

3. Abacı A, Öktem MA, Ünal E, Türkmen MA. Utility Of The Serum C - Reactive Protein And Procalcitonin For Detection Of Occult Bacterial Infection In 3-36 Month Old Children. Journal of Ankara University Faculty of Medicine 2008; 61:82-9.

4. Verma S, Szmitko PE, Ridker PM. C-reactive protein comes of age. Nat Clin Pract Cardiovasc Med 2005; 2: 29-36.

5. Taşar MA, Demir H, Atay G, Arikan Fİ, Dallar YB. Akut Odağ Olmayan Ateşli Çocuklarda İdrar Yolu İnfeksiyonunu Öngörmede C-reaktif Protein, Prokalsitonin, İnterlökin-6 Düzeylerinin Değeri. J Pediatr Inf 2014;8:165-70.

6. Dursun A, Ozsoylu S, Akyildiz BN. Neutrophil-to-lymphocyte ratio and mean platelet volume can be useful markers to predict sepsis in children.Pak J Med Sci. 2018; 34:918-22. doi: 10.12669/ pjms.344.14547.

7. Han SY, Lee IR, Park SJ, Kim JH, Shin JI. Usefulness of neutrophil-lymphocyte ratio in young children with febrile urinary tract infection.Korean J Pediatr 2016; 59:139-44. doi: 10.3345/ kjp.2016.59.3.139.

8. Aydın İ, Ağıllı M, Aydın FN, Kurt YG, Caycı Tuncer, Taş A,ve ark. Farklı yaş gruplarında Nötrofil/Lenfosit oranı referans aralıkları.Gülhane Tip Derg 2015;57: 414-8. doi: 10.5455/gulhane. 166398

9. Aksoy V, Şen V, Tan İ. Toplum Kökenli Pnömoni Tanısı ile Hastaneye Yatırılan Çocukların Değerlendirilmesi. Arch Pediatr 2016;1:27-34.

10. Anderson EC, Ingle SM, Muir P, Beck C, Finn A, Leeming JP, Cabral C, et al. Community paediatric respiratory infection surveillance study protocol: a feasibility, prospective inception cohort study. BMJ Open 2016; 31;6:e013017. doi: 10.1136/ bmjopen-2016-013017.

11. Loonen AJ, de Jager CP, Tosserams J, Kusters R, Hilbink M, Wever PC, van den Brule AJ. Biomarkers and molecular analysis to improve bloodstream infection diagnostics in an emergency care unit. PLoS One 2014;9:87315.
12. Bekdas M, Goksugur SB, Sarac EG, Erkocoglu M, Demircioglu F. Neutrophil/lymphocyte and C-reactive protein/mean platelet volume ratios in differentiating between viral and bacterial pneumonias and diagnosing early complications in children. Saudi Med J 2014;35:442-7.

13. Kaya Z, Küçükcongar A, Vurallı D, Emeksiz HC, Gürsel T. Leukocyte Populations and C-Reactive Protein as Predictors of Bacterial Infections in Febrile Outpatient Children. Turk J Hematol 2014;31:4955

14. Tekin M, Çalışkan MN, Kayak D,Konca Ç. C-reaktif protein bakteriyel infeksiyon tanısında güvenilir bir belirteç midir? Adıyaman Üni. Sağlık Bilimleri Derg, 2017;3:475-86.

15. Qu J, L X, Liu Y, Wang X. Evaluation of procalcitonin, C-reactive protein, interleukin- 6 \& serum amyloid $\mathrm{A}$ as diagnostic biomarkers of bacterial infection in febrile patients. Indian J Med Res. 2015;141:315-21.

16. Wu CW, Wu JY, Chen CK, Huang SL, Hsu SC, Lee MT, Chang SS, et al. Does procalcitonin, C-reactive protein, or interleukin- 6 test have a role in the diagnosis of severe infection in patients with febrile neutropenia? A systematic review and meta-analysis. Support Care Cancer 2015; 23:2863-72. doi: 10.1007/s00520-015-2650-8.

17. Gauchan E, Adhikari S. C-reactive Protein Versus Neutrophil/ lymphocyte Ratio in Differentiating Bacterial and Non-bacterial Pneumonia in Children.J Nepal Health Res Counc 2016;14:1548

18. Proctor MJ, McMillan DC, Morrison DS, Fletcher CD, Horgan PG, Clarke SJ. A derived neutrophil to lymphocyte ratio predicts survival in patients with cancer. Br J Cancer 2012;107:695-9.

19. Atan D, Apaydın E, Özcan KM, Dere H. New diagnostic indicators in chronic otitis media with effusion: neutrophil to lymphocyte ratio and thrombocyte lymphocyte ratio. ENT Updates 2016;6:12-15 doi:10.2399/jmu.2016001007.

20. Mentis AF, Kyprianou MA, Xirogianni A, Kesanopoulos K, Tzanakaki G. Neutrophil-to-lymphocyte ratio in the differential diagnosis of acute bacterial meningitis.Eur J Clin Microbiol Infect Dis 2016;35:397-403. doi: 10.1007/s10096-015-2552-1.

21. Forget P, Khalifa C, Defour JP, Latinne D, Van Pel MC, De Kock $\mathrm{M}$. What is the normal value of the neutrophil-to-lymphocyte ratio? BMC Res Notes. 2017;10:12. doi: 10.1186/s13104-0162335-5. 